\title{
PERSPEKTIEF
}

\section{DIE EENHEID VAN DIE UNIVERSITEIT}

Dit lyk na 'n teenstrydigheid om te besin oor die eenheid van 'n universiteit. Die naam "universiteit" is tog afgelei van die Latynse woord ,universitas", wat in die amptelike stukke van die meeste Europese lande vandag nog gebruik word. Hierdie woord beteken "die geheel" en dit veronderstel natuur. lik dadelik eenheid.

So was die ontwikkeling van die universiteit inderdaad ook. In die antieke periode het die leermeester die eenheid gegee - 'n ideale eenheid terwyl beide die wetenskap en die getal studente dit nog kon toelaat. In die laat middeleeue en renaissance het die onderliggende inhoudstruktuur die eenheid verskaf, want alle studente moes basies 'n sekere leergang afhandel en die beperktheid in verspreiding van kursusse het die eenheid sterk beklemtoon. Daarby kom nog die isolasie van die universiteit en sy verhewenheid bo die gewone lewe.

Sedert die negentiende en in die twintigste eeu het die universiteit so ontwikkel, nie alleenlik wat studentegetalle maar ook wat funksies betref, dat die gebrek aan eenheid 'n aktuele probleem geword het. Studente in die verskillende fakulteite neem net nie meer dieselfde kursusse nie, en die paaie loop al verder uit mekaar. Hierdie geskeidenheid bring probleme mee en verskillende pogings word vandag in werking gestel om die eenheidsband tussen student en student, tussen kursus en kursus, tussen fakulteit en fakulteit so ver as moontlik weer ' $n$ realiteit te maak.

' $n$ Eenvoudige weg is daar skynbaar nie, en oor-idealistiese verwagtings moet liewer nie gekoester word nie. Die verskeidenheid en uiteenlopendheid is nou eenmaal te groot om malklik of honderd persent effektief oorkoepel te word. 'n Onrealistiese gedwongenheid sal ook misluk en selfs nog skade berokken. Elke universiteit in Suid-Afrika het seker al aandag aan hierdie saak gegee, sommige meer en ander minder. Die resultate is natuurlik ook net so wisselend.

Aan die P.U. vir C.H.O. is daar ook meer as twee dekades reeds hard geworstel met hierdie probleem, en gaandeweg is 'n struktuur uitgebou wat nie daarop roem dat dit ' $n$ afdoende en finale oplossing vir die behoud van eenheid aanbied nie, 
maar wat onder huidige omstandighede sekerlik op 'n mate van sukses aanspraak kan maak.

Hierdie aksie om die gebondenheid en eenheid te beklemtoon word van verskillende kante aangepak en moet juis daardeur sy doel bereik. 'n Suksesvolle weg net van een hoek af kan nie gevind word nie; daarvoor is die universiteit te gekompliseerd.

Ek meen ons kan drie duidelike pylers aandui wat as basiese struktuur aan ons universiteit ' $n$ fundamentele en organiese eenheid verseker:

1. Die beginselgrondslag. Dit is ' $n$ diensvoorwaarde van 'n dosent alhier om die wetenskap volgens Christelike beginsels te beoefen en te bevorder. Die uitvoering van hierdie diensplig bring mee dat elke rigting van die wetenskap met 'n sentrale punt - die Christelike beginsel - verbind word. Daar is dus ' $n$ goue draad van gebondenheid wat ' $n$ breër baan het as wat mens eers dink, want dit vereis 'n redelike mate van wetenskaplike inhoud. 'n Universiteit wat nie hierdie eenheidsfaktor het nie mis die diepste eenheidsgrond wat moontlik denkbaar is, terwyl die een wat dit het reeds 'n geweldige voorsprong geniet.

2. Vir alle studente 'n verpligte kursus, wat ons Interfakultere Wysbegeerte noem, en wat oor die drie voorgraadse jare geneem word. Hoewel die eenheid van die universiteit op verre na nie die enigste doelwit van hierdie kursus is nie, kan dit nie anders as om 'n sterk eenheidsband tussen kursus en kursus en fakulteit en fakulteit te le nie want verskeie aspekte van lewensbeskouing soos dit sy neerslag in verskillende wetenskappe vind en ook wetenskapsleer self is ' $n$ essense van die kursus. Hierin tog vind mens die elemente wat die eenheid bepaal. Persoonlik ag skrywer hiervan die intrinsieke waarde van so ' $n$ kursus baie hoog, al lyk dit soms of dit as verpligte kursus nie hierdie doel bereik nie. Daar bestaan egter geen twyfel nie dat ' $n$ waardevolle aanslag op en aanvulling by die geestesinhoud van elke student plaasvind.

3. Behalwe die formele byeenkomste soos by ' $n$ opening of sluiting of spesiale geleenthede is dit noodsaaklik dat op meer akademiese vlak ' $n$ eenheidsfront van 'n universiteit getoon word. Vir hierdie doel is elf jaar gelede die "inter- 
fakultêre lesings" ingestel waardeur die universiteite as geheel in staat gestel word om rondom ' $n$ bepaalde tema die gedagtegange in die verskillende fakulteite op te vang. Hier het ons die ideale eenheidsmonstering van dosente en studente - dus die ware universiteit. In hierdie uitgawe vind die leser vanjaar se lesings. $U$ sal opmerk dat daar ' $n$ sentrale gedagte „,kultuurbestemming" deur al die lesings loop. Dit is die akademiese eenheid, en die samesyn van dosente en studente is die fisiese eenheid.

As ons let op die volgende temas wat reeds afgehandel is, is dit baie duidelik dat hieruit 'n sterk inspirasie en leiding vir die hele universiteit spreek:

1959: Die mens en - sy wese.

1960: Persoonlikheid.

1961: Lewe en dood.

1962: Eenheid en verskeidenheid in die skepping van God.

1963: Erfenis en ontwikkeling.

1964: Vryheid en gebondenheid.

1965: Vryheid en gebondenheid.

1966: Invloede op die Suid-Afrikaanse beskawingspatroon.

1967: Ontwikkeling en perspektief.

1968: Hedendaagse probleme van Suid-Afrika.

Hierdie temas is deur vakmense volgens gesigspunte vanuit verskillende fakuteite behandel en die eenheidsband en weder. sydse begrip is daardeur onberekenbaar bevorder. Elke jaar ervaar die P.U. vir C.H.O. die glanspunt van 'n eenheidskonfessie; deur die dekades heen moet dit die komponente en variante van kursusse en fakulteite stewig aan mekaar heg.

Die P.U. vir C.H.O. is dus in 'n gunstige posisie geplaas omdat hierdie drie metodes van saambinding van die universiteit tot sy beskikking is. Maar saambinding alleen is nie die hoogste doelwit nie, dit moet op sy beurt weer 'n middel wees tot die vorming en bestendiging van 'n eie styl en karakter dwarsdeur die universiteit as 'n geheel. Dit is die enigste weg om 'n Christelike stempel te bekom en deur te dring tot die diepste gronde van die geestesstruktuur van elke student en daar ' $n$ blywende beginselinhoud te laat kristalliseer. Die ideaal van die universiteit is dat elke dosent op sy gebied 'n Christelike oriëntering van sy vak gee en sy wetenskaplike denke op daardie lees skoei; dat elke student deur die kursus 
Interfakultère Wysbegeerte 'n perspektief op die lewensbeskoulike vir homself sal bekom, en dat 'n eenheidsmonstering deur die interfakultere lesings vergesigte en inspirasie sal meebring. Hoe meer die universiteit hierdie ideaal kan verwesenlik, hoe nader sal hy kom aan die realisering van sy besondere roeping as dié universiteit in Suid-Afrika met 'n uitgesproke en beskrewe Christelike grondslag.

W. N. Coetzee.

P.U. vir C.H.O. 